\title{
Innovativeness and Factors that Affect the Information Technology Adoption in the Classroom by Primary Teachers in Chile
}

\author{
Valentina A. LÓPEZ-PÉREZ1 ${ }^{\text {, Patricio E. RAMÍREZ-CORREA², }}{ }^{2 *}$ \\ Elizabeth E. GRANDÓN ${ }^{1}$ \\ ${ }^{1}$ Facultad de Ciencias Empresariales, Universidad del Bío-Bío, Concepción, Chile \\ ${ }^{2}$ Escuela de Ingeniería, Universidad Católica del Norte, Coquimbo, Chile \\ e-mail:vlopezp@ubiobio.cl; patricio.ramirez@ucn.cl; egrandon@ubiobio.cl
}

Received: November 2018

\begin{abstract}
This research examines the factors that influence the intention to use information technology in the classroom by primary school teachers based on the Unified Theory of Acceptance and Use of Technology and their technological predisposition. In particular, the relationship between teachers' innovativeness and their beliefs associated with the use of technology in the classroom was analyzed. To this end, 212 teachers from three provinces of Chile were surveyed. Data were analyzed using partial least squares statistical technique. Results indicate that performance expectancy, social influence, and facilitating conditions influence the intention to use information technology in the classroom. It was found that the intention to use construct is a determinant of the use of technology, which validates the robustness of the model in a context of primary education. In addition, it was validated that teachers' innovativeness determines their beliefs about the use of information technology in the classroom.
\end{abstract}

Keywords: technology adoption, innovativeness, primary school, Chile.

\section{Introduction}

The access to and use of information and communication technologies (ICTs) has revolutionized our daily lives, allowing us to perform actions that were previously unthinkable in the way and with the instantaneity that these technologies offer. Moreover, they have transformed the "concepts of space and time, the range and speed with which information is generated and made it available to users; it is a society of learning to learn" (Cabrero \& Llorente, 2015). In the education field, ICTs have been incorporated with the goal of transforming and improving the school system. Over

\footnotetext{
* Corresponding Author
} 
the past decades, countries have revised their education systems and created numerous initiatives and made efforts to encourage the use of ICTs in the teaching-learning process (Hepp, 2015).

In the case of Chile, the state has substantiated advances in technology infrastructure and in network access (Sunkel, 2006), focusing mainly on two aspects: a) curricular changes in various areas of pedagogy in order to incorporate the use of ICTs into the initial formation of teachers (Silva, Gros, Garrido \& Rodríguez, 2006) and b) offering teachers professional development opportunities (Contreras-Sanzana \& VillalobosClavería, 2010), workshops, and support (Sunkel, 2006). It has been shown that ICTs allow lowering students' digital divide, empowering them in the digital society, and transmit curricular content in a playful, interactive, and innovative manner. In addition, ICTs are instruments for information processing which allow educational spaces for cognitive development (Villegas, Mortis, García, \& Del Hierro, 2017). However, according to standardized tests that have been applied, the advantages of adopting ICTs in the classroom have not been reflected in the results of the Chilean student body (Jara \& Claro, 2012). In addition, there is no evidence of any significant change in the way contents are delivered utilizing ICTs in the classroom by teachers (Puentes, Roig, Sanhueza, \& Friz, 2014).

In light of the above-mentioned situation, it is necessary to investigate possible barriers that affect the incorporation of ICTs in the teaching-learning process. Authors such as Pelgrum (2001) identified material and non-material obstacles. Material obstacles include limited access to computers, software, and internet connection. Non-material obstacles are the instructor's insufficient knowledge about ICTs, the difficulty of integrating ICTs in the educational process, and insufficient time available. Other research has been detected that teachers display attitudes, beliefs, and prior experiences related to ICTs that do not facilitate their incorporation in the classroom, such as mistrust and fear (Hinojo, Fernández, \& Aznar, 2002). Furthermore, more recent research points out that, although teachers have access to technology and are obligated by the school administration to use it, they exercise their own will when the time comes to incorporate ICTs in the classroom (Yang \& Huang, 2008). Teachers may have knowledge of ICTs, but not necessarily believe in the technology's potential and, therefore, they do not incorporate it into the teaching-learning process (Blackwell, Lauricella, Wartella, Robb, $\&$ Schomburg, 2013). In addition, Viñals and Cuenca also identify the fear of teachers when exposed to the use of ICTs (Viñals \& Cuenca, 2016).

Therefore, it is fundamental to the process of adopting ICTs by teachers to determine the capacities, attitudes, and ideas they have concerning technology (Claro, 2010). In this sense, it is desirable to have an active and positive attitude, highly motivating for the student body (Hinojo et al., 2002), since the teachers are the ones who should have the capacity to transmit educational content in an innovative way, stimulating the use of ICTs, and generating new knowledge without ceasing to reach high, desirable academic levels by utilizing technology (Valencia-Molina et al., 2008) (UNESCO, 2004). Being the teachers a determining piece in the process of ICTs incorporation in the classroom, it is essential to investigate their processes of adoption of technology and determine whether the innovative characteristics of them are related to the intention to use ICTs in the classroom. This study addresses technology adoption using the Unified Theory 
of Acceptance and Use of Technology (Venkatesh et al., 2003) and the innovative characteristics of the teachers by utilizing the model of Technological Readiness Index (Parasuraman, 2000).

\section{Theoretical Background}

\subsection{Unified Theory of Acceptance and Use of Technology}

The Unified Theory of Acceptance and Use of Technology (UTAUT) is a theory that predicts people's intention and use of technology (Venkatesh et al., 2003). In order to develop this theory, the authors meticulously studied different intention models: The Diffusion of Innovation Theory (Rogers, 1962), The Theory of Reasoned Action (Fishbein \& Ajzen, 1975), The Technology Acceptance Model (Davis, 1989), The Theory of Planned Behaviour (Ajzen, 1991), Social Cognitive Theory (Compeau, Higgins, \& Huff, 1999), Expectancy Confirmation Theory (Oliver, 1980), The Model of Personal Computing Utilization (Thompson, Higgins, \& Howell, 1991), and the Motivational Model (Davis, Bagozzi, \& Warshaw, 1992). After revising and analyzing the previous theories, the authors created a unified model with four antecedents of the behavioral intention to use technology (BI): performance expectancy (PE), effort expectancy (EE), social influence (SI), and facilitating conditions (FC). Furthermore, facilitating conditions and intention to use ICTs were considered as determinants of the actual use. The authors also included moderating variables in the relations, such as age, gender, experience, and willingness to use ICTs. Fig. 1 shows the unified model proposed by Venkatesh et al. (2003).

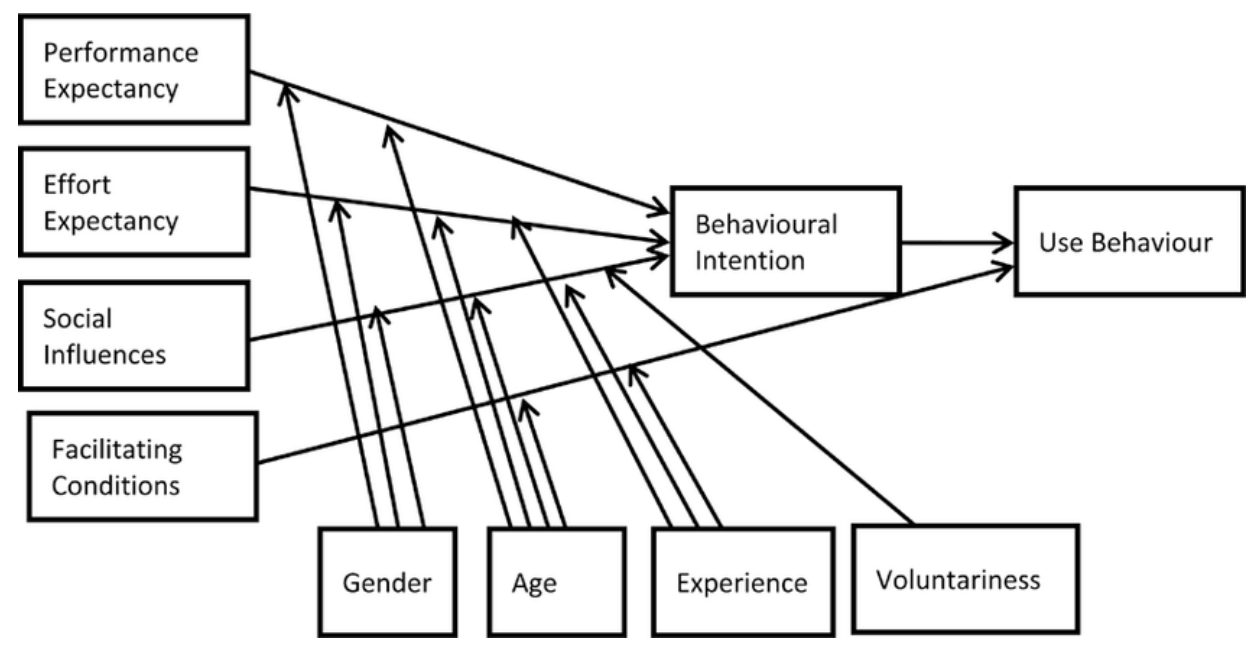

Fig. 1. Unified Theory of Acceptance and Use of Technology. 
PE is defined as the "extent to which an individual believes that the use of the system will help him/her to obtain benefits in their work performance". EE corresponds to the "degree of ease associated with the use of the system". SI is defined as the "extent in which an individual believes that significant people for him/her think that he/she should or shouldn't use a system, innovation or a certain technology". Finally, FC is defined as the "extent in which a person considers that there is an organizational and technological infrastructure to support the use of the system". With this unified model, the authors explained approximately $70 \%$ of the variance in BI, a value for which this model and its later variations have been widely used in different investigations related to diverse technologies and contexts (Aldunate \& Nussbaum, 2013; Ramirez-Correa, Rondan-Cataluña, Arenas-Gaitán, 2014; Ramirez et al., 2018, Grandón et al., 2018).

\subsection{Technological Predisposition}

The Technology Readiness Index (TRI) developed by Parasuraman, recognizes the importance of attitude or technological predisposition as a key factor in the adoption of cutting edge technology in the home or at work. This scale consists of 36 items and is grouped into four dimensions: optimism, innovativeness, discomfort, and insecurity. Optimism is defined as the positive belief about technology, which offers people an improvement of control, flexibility, and efficiency in their lives. Innovativeness refers to one's tendency to be a pioneer of technology and intellectual leader, to want to experiment, learn, and talk about technology. Discomfort, on the other hand, is a perception of the loss of control over technology, and a sensation of being overwhelmed by it. Finally, insecurity is defined as a belief of distrust about technology and skepticism with respect to its proper operation (Parasuraman \& Colby, 2001). Optimism and innovativeness are considered motivators of user's predisposition to use technology, whereas discomfort and insecurity are considered aspects that act as inhibitors of the predisposition (Parasuraman, 2000). Fig. 2 shows these four constructs associated with being contributors or inhibitors of technology use.

After a decade, Parasuraman \& Colby (2015) updated the TRI scale considering the changes associated with the technology and with the intention of making the measuring instrument simpler. They developed TRI 2.0 based on a scale of 16 items distributed in the same four dimensions (optimism, innovativeness, discomfort, and insecurity) which explain $61 \%$ of the variance through the items. From the four dimensions that measure the predisposition towards technology, the innovative behavior of teachers is considered relevant for this study.

Previous research has established that people with innovative characteristics are the first to adopt technologies and usually learn to use them by themselves (Parasuraman \& Colby, 2001). However, it has been found that the innovativeness (INN) variable has a significant inverse relationship with the intention to use technology, given that people with high levels of INN tend to not continue using the technology (Bravo, Ramírez-Correa, \& Arenas, 2018; Zampieri, Lindner, Flores, \& Pellegrin, 2014). This can be associated with the fact that these individuals exhibit great expectations for 


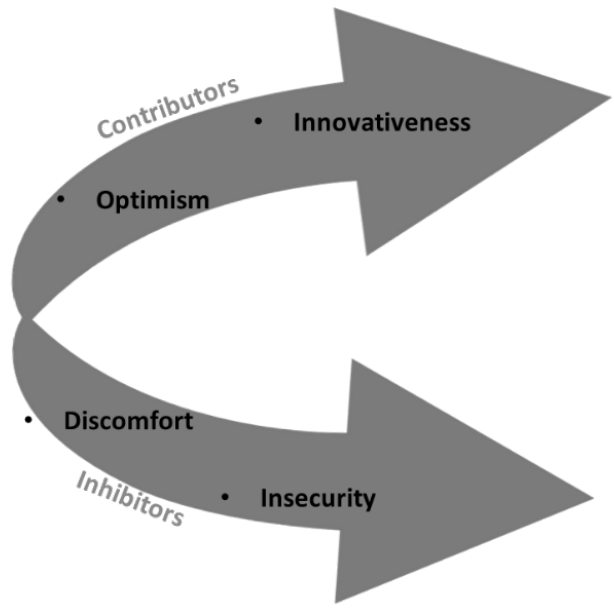

Fig. 2. Technology Readiness Index.

the adoption of technology and constantly look for new products (Zanardo \& Dada1to, 2010). INN has been used in previous research as a determinant of the intention to use diverse technologies. For example, it has been included as a direct antecedent of the intention of using or continue using technologies associated with the Internet (Koenigstorfer \& Groeppel-Klein, 2012; Lam, Chiang, \& Parasuraman, 2008). INN has also been included in the UTAUT theory in order to better explain the phenomenon of adoption. For instance, Borrero et al. (2014) found that innovativeness moderates the relation between the constructs of UTAUT and student's intentions to use social networks in Spain.

\section{Research Model and Hypotheses}

The UTAUT adoption model has been utilized to understand the use of technologies associated with the field of secondary and higher education. For example, considering the little use of e-learning technologies by teachers in a higher education institution in Portugal, Marques et al. (2011) explored UTAUT as a theoretical model to understand the adoption phenomenon. The authors did not apply the model to predict the intention to use e-learning technology, but they suggest that UTAUT is an adequate model for studying the phenomenon. Other studies, which have used UTAUT to explain the factors that influence the acceptance of different types of ICTs in the classroom, demonstrate that the explained variance for the combination of variables in the UTAUT model reaches between $27 \%$ and $35 \%$, finding that the stronger predictors of intention are effort expectancy, performance expectancy, and social influence (Birch \& Irvine, 2009; Pynoo et al., 2011; Oye, AIahad, \& AbRahim, 2014). On the contrary, in the studies by Raman \& Rathakrishnan (2018) y Martín, García, \& Muñoz (2014), effort expectancy was not found to be a significant predictor of the ICTs use by teachers in 
models that explain a $35 \%$ and $42.1 \%$ of the variance in the intention of use respectively. In this way, taking the UTAUT model as a theoretical model and considering the diversity of the results, this study is expected to determine which of the four constructs, performance expectancy, effort expectancy, social influence or facilitating conditions have an influence in the intention to use ICTs by teachers in primary schools in the Biobío region of Chile.

Furthermore, previous studies have investigated the relationship between the technological disposition of individuals and their perceptions about the ease of use and usefulness of technology. For example, Walczuch et al. (2007) argue that the majority of people use only part of the functionality of the systems in their companies, and this could be due to their personality characteristics. For this reason, the authors generated a model based on the four personality components of TRI to determine their impact in the cognitive dimensions of the Technology Acceptance Model (TAM). This model includes perceptions of ease of use and usefulness as antecedents of the intention to use technology. To this end, they gathered employee information from a company that supplies financial services, concluding that personality characteristics influence the perceptions of ease of use and usefulness of technology. In a similar study, Lin et al. (2007) integrated the technological predisposition with the TAM model in the context of the adoption of electronic service systems by consumers. Their results help explain why people who score high in the index of technological disposition do not always adopt cutting-edge technology. The authors indicate that characteristics of the systems and the ease of use and usefulness, intervene in the explanation of the adoption phenomenon. More recent studies have followed this same line of inquiring; for instance, Hallikainen \& Laukkanen (2016) and Larasiti et al. (2017) validated the importance of considering personality characteristics associated with TRI as predecessors of the perceptions of ease of use and usefulness of B2B technologies and ERP systems respectively.

The dimensions of the TRI model, optimism, innovativeness, discomfort, and insecurity have also been found as antecedents of the constructs associated with the UTAUT theory. This is the case of Seol et al. (2017) who state that there are positive and significant relationships between the dimensions of TRI and the basic components of the UTAUT theory in the context of the use of portable smart devices for sports. Through an analysis of structural equations, the authors validated all these relationships and found that the intention to use these devices explains their use. Therefore, there is previous evidence that supports the relationship between the predisposition that an individual has towards technology and his/her perceptions regarding the use of it. Then, and following previous studies, the following hypotheses are proposed:

H1: The innovativeness of the teachers is positively related to the performance expectancy associated with the use of ICTs in the classroom.

H2: The innovativeness of the teachers is positively related to the effort expectancy associated with the use of ICTs in the classroom.

H3: The innovativeness of the teachers is positively related to the social influence they perceive of using ICTs in the classroom. 


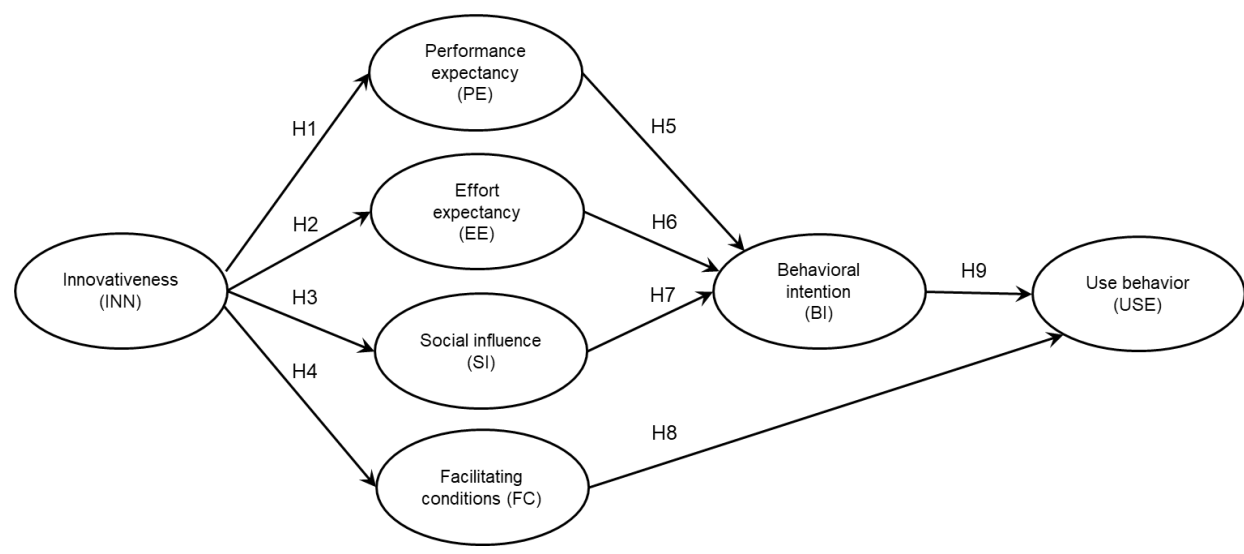

Fig. 3. Proposed research model.

H4: The innovativeness of the teachers is positively related to the facilitating conditions they perceive of using ICTs in the classroom.

H5: Performance expectancy is positively related to the intention to use ICTs in the classroom by teachers.

H6: Effort expectancy is positively related to the intention to use ICTs in the classroom by teachers.

H7: Social influence is positively related to the intention to use ICTs in the classroom by teachers.

H8: Facilitating conditions are positively related to the use of ICTs in the classroom by teachers.

H9: The intention to use ICTs in the classroom is positively related to the use of ICTs in the classroom by teachers.

\section{Methodology}

The empirical study is based on a cross-sectional design with the use of a questionnaire to collect the data. The study population is made up of teachers from primary schools in the three provinces of Chile, Arauco, Biobío, and Concepción, including public, subsidized, and private schools. The fieldwork was carried out in the months of May and June 2018.

For the fieldwork, school directors were contacted to let them know the objective of the study and they were given the questionnaires, which were then collected at a later date. The data collection instrument is a questionnaire that was structured in two sections: demographic information of the teacher and the school and a set of items or indicators based on the theoretical framework of the proposed model. In this last section, Likert-type scales graded from "totally disagree" to "totally agree" were used to measure the indicators of the latent variables of the UTAUT model (Venkatesh et al., 
2003). Previously, content validity of the questionnaire was analyzed through a pilot study applied in December 2017, in which 33 teachers from primary schools located in the province of Concepción participated. As a result, the wording of an item (PE3) related to the performance expectancy latent variable was changed, since showed a very low load in its respective construct.

For data processing and considering the exploratory nature of this research, structural equation models analysis was utilized, using partial least squares (PLS) (Ringle, Wende, \& Will, 2015). PLS is based on two stages: analysis of measurement model (reliability and validity) and evaluation of the relations between the latent variables of the model, which are represented in the structural model.

\section{Results}

As a result of the data collection process, 212 valid surveys were obtained, which are distributed according to the following: 48 individuals from Arauco, 57 individuals from Biobío, and 107 individuals from Concepción. Table 1 shows demographic information of the research subjects and information associated with the schools.

In order to determine the reliability and validity of the instrument, different indicators are used in PLS. Among them are the item individual reliability, the composite reliability, the internal consistency of the scale, and the convergent and discriminant validity. Next, each of these indicators is analyzed.

The individual reliability of the items evaluates the loads $(\lambda)$ or simple correlations of each indicator connected to their respective latent variables. According to Carmines \& Zeller (1979), values above 0.707 are considered satisfactory, although Chin (1998) and Falk \& Miller (1992) indicate that values above 0.5 are acceptable. When running the PLS algorithm, the load of two items of the INN was under the acceptable standards (TRI1 with $\lambda=0.661$ and TRI2 with $\lambda=0.566$ ). Furthermore, the value obtained for this construct in the Cronbach's alpha coefficient was 0.657 and in the average variance extracted 0.496 , for this reason, items INN1 and INN2 were eliminated from the construct. Similarly, item FC3 was eliminated from FC construct, since, although it had an acceptable load value, it did not contribute to the Cronbach's alpha of the construct. Subsequently, the PLS algorithm was rerun. The results are presented in Table 2 .

In addition to the individual reliability of the items, the reliability of the construct was evaluated through the composite reliability indicator and internal consistency. The results are satisfactory according to the criteria defined by Nunnally (1978) and Cepeda \& Roldán (2004) who suggest a value for construct reliability greater than or equal to 0.7. As presented in Table 3, composite reliability (CR) of all constructs meets the suggested criteria. On the other hand, the internal consistency of the instrument was measured through the Cronbach alpha coefficient (CA). The results obtained in the model are very good, considering the criteria presented by George \& Mallery (2003). Table 3 shows that all CA are much greater than 0.7 . The convergent validity of the instrument refers to determining if the indicators that measure a latent variable are really measur- 
Table 1

Demographic information of teachers and schools

\begin{tabular}{llrr}
\hline Variable & Category & Total & Frequency \\
\hline Province & Arauco & 48 & $23 \%$ \\
& Biobío & 57 & $27 \%$ \\
& Concepción & 107 & $50 \%$ \\
Profession & High School Teacher* & 54 & $25 \%$ \\
& Elementary School Teacher & 99 & $47 \%$ \\
& Special Education Teacher & 23 & $11 \%$ \\
& Nursery Teacher & 16 & $8 \%$ \\
& Other major & 20 & $9 \%$ \\
Gender & Masculine & 37 & $17 \%$ \\
& Femenine & 171 & $81 \%$ \\
& No Information & 4 & $2 \%$ \\
School type & Public & 120 & $57 \%$ \\
& Private school & 15 & $7 \%$ \\
& Subsidized & 77 & $36 \%$ \\
Age range & 21 to 31 & 65 & $31 \%$ \\
& 32 to 41 & 64 & $30 \%$ \\
& 42 to 51 & 48 & $23 \%$ \\
& 52 to 65 & 29 & $14 \%$ \\
& No Information & 6 & $3 \%$ \\
\hline
\end{tabular}

* High school teachers who work at elementary or middle school.

Table 2

Item loads of each construct

\begin{tabular}{lllllllllllllll}
\hline PE & \multicolumn{3}{c}{ EE } & \multicolumn{3}{c}{ SI } & \multicolumn{3}{c}{ FC } & \multicolumn{3}{c}{ BI } & \multicolumn{3}{c}{ INN } & \multicolumn{3}{c}{ USE } \\
\hline PE1 & 0.800 & EE1 & 0.823 & SI1 & 0.718 & FC1 & 0.844 & BI1 & 0.918 & INN3 & 0.877 & USE1 & 0,929 \\
PE2 & 0.842 & EE2 & 0.902 & SI2 & 0.681 & FC2 & 0.736 & BI2 & 0.916 & INN4 & 0.902 & USE2 & 0,873 \\
PE3 & 0.858 & EE3 & 0.876 & SI3 & 0.832 & FC4 & 0.793 & BI3 & 0.929 & & & & \\
PE4 & 0.780 & EE4 & 0.876 & SI4 & 0.836 & & & & & & & & \\
\hline
\end{tabular}

Table 3

Composite Reliability, Cronbach's Alpha, and Average Variance Extracted

\begin{tabular}{llll}
\hline Construct & CR & CA & AVE \\
\hline BI & 0.944 & 0.911 & 0.848 \\
EE & 0.925 & 0.892 & 0.756 \\
FC & 0.835 & 0.703 & 0.628 \\
INN & 0.884 & 0.737 & 0.792 \\
PE & 0.891 & 0.838 & 0.673 \\
SI & 0.852 & 0.778 & 0.593 \\
USE & 0.896 & 0.772 & 0.812 \\
\hline
\end{tabular}


ing the same. The average variance extracted (AVE) indicator was used for the assessment of convergent validity. According to the acceptance criteria suggested by Fornell \& Larcker (1981), values higher than 0.5 are considered satisfactory. Table 3 shows that the AVE values are satisfactory for all latent variables.

In the analysis of discriminant validity, cross-correlations are evaluated. Therefore, it is expected to prove that the constructs have a greater correlation with their measurement indicators than with the rest of the variables. In other words, it is intended to measure whether a construct is different from the other constructs of the model. According to the criteria defined by Fornell \& Larcker (1981), the results obtained are satisfactory since the values of the correlations between the same constructs are greater or equal than the values of the correlations with different constructs. Table 4 shows the results obtained.

Once it has been determined that the measuring instrument is reliable and valid, we proceed to evaluate the structural model. The path coefficients $(\beta)$, the variance explained $\left(\mathrm{R}^{2}\right)$, the $\mathrm{t}$ statistics, and the $\mathrm{p}$-values are used for this evaluation. The results are shown in Table 5.

Table 4

Discriminant Validity

\begin{tabular}{llllllll}
\hline Construct & FC & PE & EE & SI & BI & INN & USE \\
\hline FC & $\mathbf{0 . 7 9 2}$ & & & & & & \\
PE & 0.605 & $\mathbf{0 . 8 2 0}$ & & & & & \\
EE & 0.655 & 0.652 & $\mathbf{0 . 8 7 0}$ & & & & \\
SI & 0.619 & 0.643 & 0.513 & $\mathbf{0 . 7 7 0}$ & & & \\
BI & 0.590 & 0.706 & 0.558 & 0.746 & $\mathbf{0 . 9 2 1}$ & & \\
INN & 0.654 & 0.572 & 0.757 & 0.498 & 0.518 & $\mathbf{0 . 8 9 0}$ & \\
USE & 0.617 & 0.623 & 0.676 & 0.565 & 0.576 & 0.708 & $\mathbf{0 . 9 0 1}$ \\
\hline
\end{tabular}

Table 5

Summary of total model effects

\begin{tabular}{llrl}
\hline Relationship & $\beta$ & t statistics & p-values \\
\hline $\mathrm{PE} \rightarrow \mathrm{BI}$ & 0.336 & 4.908 & 0.000 \\
$\mathrm{EE} \rightarrow \mathrm{BI}$ & 0.091 & 1.536 & 0.125 \\
$\mathrm{SI} \rightarrow \mathrm{BI}$ & 0.484 & 7.859 & 0.000 \\
$\mathrm{FC} \rightarrow \mathrm{USE}$ & 0.425 & 7.003 & 0.000 \\
$\mathrm{INN} \rightarrow \mathrm{PE}$ & 0.572 & 11.736 & 0.000 \\
$\mathrm{INN} \rightarrow \mathrm{EE}$ & 0.757 & 24.377 & 0.000 \\
$\mathrm{INN} \rightarrow \mathrm{SI}$ & 0.498 & 9.234 & 0.000 \\
$\mathrm{INN} \rightarrow \mathrm{FC}$ & 0.654 & 15.153 & 0.000 \\
$\mathrm{BI} \rightarrow \mathrm{USE}$ & 0.326 & 5.077 & 0.000 \\
\hline
\end{tabular}


BI obtained an $\mathrm{R}^{2}$ of 0.649 , which means that $65 \%$ of the variance of the intention to use construct is explained by the latent variables PE, EE, and FC. Furthermore, USE obtained an $\mathrm{R}^{2}$ of 0.450 , which means that $45 \%$ of the variance of the construct is explained by BI. Table 6 shows the $\mathrm{R}^{2}$ per construct.

Fig. 4 shows the obtained PLS results represented in the research model. As can be seen, the innovativeness of teachers explains significantly to the latent variables PE, EE, SI, and FC. It can also be seen in the figure that PE, SI, and FC are factors that significantly explain the intention to use ICTs in the classroom. Contrary to expectations, EE does not contribute to explaining the intention to use. On the other hand, the results indicate that $\mathrm{BI}$ and $\mathrm{FC}$ are variables that significantly predict the use of ICTs in the classroom by teachers.

Given that UTAUT incorporates gender, age, experience, and willingness to use technology as moderating variables in the model (Fig. 1), in this current study it was determined whether gender and age have any impact on the adoption of ICTs by teachers of elementary and middle schools. It is assumed that the use of ICTs is voluntary and previous experience was not considered relevant since teachers in Chile have a high ICT knowledge (Arancibia, Cosimo, \& Casanova, 2018). First, it was evaluated whether

Table 6

$\mathrm{R}^{2}$ per construct

\begin{tabular}{ll}
\hline Construct & $\mathrm{R}^{2}$ \\
\hline USE & 0.450 \\
BI & 0.649 \\
SI & 0.248 \\
EE & 0.573 \\
PE & 0.327 \\
FC & 0.427
\end{tabular}

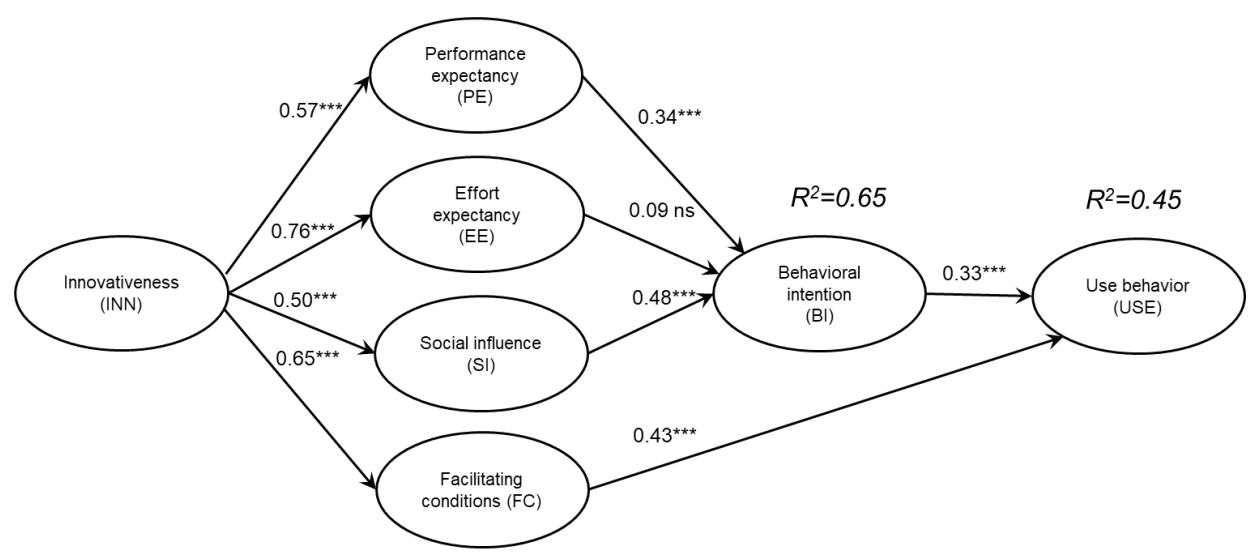

ns: not significant: * $p<0.05:{ }^{* *} \mathrm{p}<0.01:{ }^{* * *} \mathrm{p}<0.001$

Fig. 4. PLS results in the research model. 
gender and age directly influence the intention and use of technology. Neither of the two variables was significant. Using the PLS-MGA (multigroup analysis technique), gender was evaluated as a moderating variable between the intention and use of ICTs, as stipulated by UTAUT. Later, it was evaluated in the SI variable. The results showed significant differences between men and women in the SI, being higher for the case of men $(0.71)$ versus women $(0.42)$. When separating the group of teachers in two age ranges, from 21 to 41 years old and from 42 to 65 years old, the PLS-MGA analysis found no significant differences in the model.

In summary, the PLS analysis results support hypotheses H1, H2, H3, H4, H5, H7, $\mathrm{H} 8$, and H9, but cannot support H6.

\section{Discussion}

From the results obtained, the high explained variance stands out by the set of variables of the extended UTAUT model used in this study, which explains $65 \%$ the intention to use and $45 \%$ the use of ICTs. These values, on the one hand, allow to validate the UTAUT model in the educational field, and on the other hand, they surpass the explanation of previous research that uses the same theory (Birch \& Irvine, 2009; Pynoo et al., 2011; Martín, García, \& Muñoz, 2014; Hey, Alahad, \& AbRahim, 2014).

Regarding the factors that most influence the adoption of ICTs by teachers, results indicate that performance expectancy, social influence, and facilitating conditions significantly predict the intention to use ICTs in the classroom. These results are in line with what has been pointed out by other authors. For example, the positive influence of the performance expectancy variable in the intention to use has been shown in Prensky's research (2011). He points out that teachers who understand what technology can achieve in the performance and learning of the students are more successful in the use of ICTs in the classroom. Social influence turned out to be one of the most significant variables that explain the intention to use technology in the educational context (Pynoo et al., 2011; Hey, AIhad, \& AbRahim, 2014). Finally, facilitating conditions are important for teachers since they perceive that the availability of resources and infrastructure limit the frequency or use of these technologies in their performance in the classroom (Ibieta, Hinostroza, Labbé, \& Claro, 2017).

Nevertheless, effort expectancy, the degree of ease that the teacher perceives in the use of ICTs in the classroom, is not a significant antecedent for this prediction. In the study conducted by Davis et al. (1989), it was determined that as the technology is learned, the relationship between the intention to use and effort expectancy decreases. The results of this research are in line with the work done by Raman \& Rathakrishnan (2018) and Martín et al. (2014) who found that all the UTAUT variables predict the intention to use technologies in the educational environment, except effort expectancy. This may be due to the fact that elementary and middle school teachers do not perceive ICTs as difficult to use since they are using them in their personal and work life (Raquimán, 2014). There are also studies that support that the level of ICT management of teachers is high and that most indicate that they are self-taught in this area (Arancibia, 
Cosimo, \& Casanova, 2018). In relation to the use construct, this research validates the UTAUT model since both, facilitating conditions and intention to use, influence the use of ICTs in the classroom by teachers.

On the other hand, the innovativeness component of TRI integrated to the UTAUT model extends the explanation of the technology adoption phenomenon in educational environments, particularly in primary education. It was found that the teacher's attitude influences the four variables of the UTAUT model. These results coincide with those found by Elliott et al. (2012), Seol et al. (2017), Lin et al. (2007), Hallikainen \& Laukkanen (2016) and Larasiti et al. (2017) regarding the impact that personality characteristics have on the beliefs of ease of use and usefulness of different technologies. Similarly, the results are congruent with those found by Seol et al. (2017) within the framework of the UTAUT theory. The current study showed that both extrinsic facilitation characteristics and personal attitudes towards technology predict the use of ICTs in the classroom by teachers.

\section{Conclusions}

According to the study of Jaramillo \& Chávez (2015) regarding ICTs and education in Chile, there are not enough studies that can identify the elements that intervene in educational practices. The purpose of this research was to determine the factors that influence both the intention to use and the use of ICTs in the classroom by primary school teachers from Chile and to explore the influence that personal characteristics have on teacher's perceptions of technology. For this, the UTAUT model of Venkatesh et al. (2003) and the technological predisposition model TRI of Parasuraman (2000), particularly the innovativeness construct, were used as a theoretical basis.

The following conclusions can be drawn from the results of this research: 1) the properties of the UTAUT instrument and its research model are validated in an educational context at the primary level in Chile; 2) teachers' intention to use ICTs is determined by performance expectancy, social influence, and facilitating conditions; 3 ) effort expectancy does not influence the intention to use ICTs by teachers; 4) the use of ICT in the classroom is determined by facilitating conditions and the intention to use ICTs; and 5) the innovative characteristic of teachers influence the technology adoption factors, namely, performance expectancy, effort expectancy, social influence, and facilitating conditions.

The most important contribution of the study was to validate a model that incorporates a personality characteristic as a predecessor of teachers' beliefs towards ICTs in the classroom. The model, validated in a sample of 212 primary and middle school teachers, was found to explain a high variance in the intention and use of technologies in the classroom.

The main limitation of this study is that only three specific provinces of Chile were analyzed, which does not allow comparisons at a national level. Future studies could replicate this research considering, for example, other regions of the country or incorporating other variables that could add to the explanation of the adoption phenomenon in educational environments, such as teachers' personal values and their influence on their personality characteristics. 


\section{References}

Ajzen, I. (1991). The theory of planned behavior. Orgnizational Behavior and Human Decision Processes, 50(2), 179-211. https://doi.org/10.1016/0749-5978(91)90020-T

Aldunate, R., \& Nussbaum, M. (2013). Teacher adoption of technology. Computers in Human Behavior, 29(3), 519-524. https://doi.org/10.1016/j.chb.2012.10.017

Arancibia, M., Cosimo, D., \& Casanova, R. (2018). Percepción de los profesores sobre integración de TIC en las prácticas de enseñanza en relación a los marcos normativos para la profesión docente en Chile a. Ensaio: Aval. Pol. Públ. Educ, 26(98), 163-184. https ://doi.org/10.1590/S0104-40362017002501119

Birch, A., \& Irvine, V. (2009). Preservice teachers' acceptance of ICT integration in the classroom: applying the UTAUT model. Educational Media International, 46(4), 295-315. https://doi.org/10.1080/09523980903387506

Blackwell, C., Lauricella, A., Wartella, E., Robb, M., \& Schomburg, R. (2013). Adoption and use of technology in early education: The interplay of extrinsic barriers and teacher attitudes. Computers \& Education, 69, 310-319. https://doi .org/10.1016/J. COMPEDU. 2013.07.024

Borrero, J., Yousafzai, S., Javed, U., \& Page, K. (2014). Expressive participation in Internet social movements: Testing the moderating effect of technology readiness and sex on student SNS use. Computers in Human Behavior, 30, 39-49. https://doi.org/10.1016/j.chb.2013.07.032

Bravo, C. J., Ramírez, P. E., Arenas, J., Bravo, C. J., Ramírez, P. E., \& Arenas, J. (2018). Aceptación del Reconocimiento Facial Como Medida de Vigilancia y Seguridad: Un Estudio Empírico en Chile. Información Tecnológica, 29(2), 115-122. https://doi .org/10.4067/S0718-07642018000200115

Cabrero, J., \& LLorente, M. del C. (2015). Tecnologías de la Información y la Comunicación (TIC): escenarios formativos y teorías del aprendizaje. Revista Lasallista de Investigación, 12, 186-193. Retrieved from http://ezproxy.ubiobio.cl:2120/ehost/pdfviewer/pdfviewer?vid=1\&sid=b20ca4d3-8584 -4781-81d0-c23abf5aa38e\%40sessionmgr4009

Carmines, E., \& Zeller, R. (1979). Reliability and Validity Assessment. SAGE UNIVERSITY PAPER. Recuperado a partir de https : //www . johnljerz.com/superduper/tlxdownloadsiteMAIN/id601.html

Cepeda, G., \& Roldán, J. (2004). Aplicando en la práctica la técnica pls en la administración de empresas. Recuperado a partir de https://idus.us.es/xmlui/handle/11441/76333

Chin, W. (1998). The partial least squares approach to structural equation modeling. En Modern Methods for business Research. 295-336. Retrieved from

https://books.google.cl/books?hl=es\&lr=\&id=EDZ5AgAAQBAJ\&oi=fnd\&pg=PA295\&dq=chin+ 1998\&ots=48sG_pq4li\&sig=CIsyjAjlLCgET Jfnf6iGopA3j6k\#v=onepage\&q=chin $1998 \& f=f a l s e$

Claro, M. (2010). Impacto de las TIC en los aprendizajes de los estudiantes: estado del arte. Retrieved fromn https://repositorio. cepal.org/handle/11362/3781

Compeau, D., Higgins, C. A., \& Huff, S. (1999). Social Cognitive Theory and Individual Reactions to Computing Technology: A Longitudinal Study. MIS Quarterly, 23(2), 145. https : //doi .org/10. 2307/249749

Contreras-Sanzana, G., \& Villalobos-Clavería, A. (2010). Educación y educadores. Educación y Educadores, 13(3), 397-417. Retrieved from

http://www.scielo.org.co/scielo.php?script=sci_arttext\&pid=S0123-12942010000300006

Davis, F. (1989). Perceived Usefulness, Perceived Ease of Use, and User Acceptance of Information Technology. MIS Quarterly, 13(3), 319. https ://doi .org/10.2307/249008

Davis, F., Bagozzi, R., \& Warshaw, P. (1989). User Acceptance of Computer Technology: A Comparison of Two Theoretical Models. Management Science, 35(8), 982-1003.

https://doi.org/10.1287/mnsc.35.8.982

Davis, F., Bagozzi, R., \& Warshaw, P. (1992). Extrinsic and Intrinsic Motivation to Use Computers in the Workplace1. Journal of Applied Social Psychology, 22(14), 1111-1132. https://doi.org/10.1111/j.1559-1816.1992.tb00945.x

Elliott, K., Meng, G., \& Hall, M. (2012). The Influence of Technology Readiness on the Evaluation of SelfService Technology Attributes and Resulting Attitude Toward Technology Usage. Services Marketing Quarterly, 33(4), 311-329. https://doi.org/10.1080/15332969.2012.715049

Falk, R. F., \& Miller, N. B. (1992). A Primer for Soft Modeling. A Primer for Soft Modeling. Akron, OH, US: University of Akron Press.

Fishbein, M., \& Ajzen, I. (1975). Belief, attitude, intention and behavior: An introduction to theory and research. Recuperado a partir de https://trid.trb.org/view/1150648 
Fornell, C., \& Larcker, D. F. (1981). Evaluating Structural Equation Models with Unobservable Variables and Measurement Error. Journal of Marketing Research, 18(1), 39. https : //doi .org/10. 2307/3151312

George, D., \& Mallery, P. (2003). SPSS for Windows Step by Step A Simple Guide and Reference Fourth Edition (11.0 update) Answers to Selected Exercises ( $4^{\mathrm{a}}$ ed.). Retrieved from https://wps.ablongman. com/wps/media/objects/385/394732/george4answers.pdf

Grandon, E., Aravena-Ibarra, A., Araya, S., Ramírez-Correa, P., \& Alfaro-Perez, J. (2018). Internet of Things: Factors that influence its adoption among Chilean SMEs. En 2018 13th Iberian Conference on Information Systems and Technologies (CISTI) (pp. 1-6). IEEE. https://doi.org/10.23919/CISTI.2018.8399183

Hallikainen, H., \& Laukkanen, T. (2016). How technology readiness explains acceptance and satisfaction of digital services in b2b healthcare sector? Association for Information Systems. Recuperado a partir de file: ///C: /Users/Valentina/Downloads/Kallikainen 2016.pdf

Hepp, P. (2015). Desafíos de las políticas de integración de tecnologías en la formación inicial y continua de los docentes. En iipe-unesco buenos aires (ed.), Mejorar los Aprendizajes en la Educación Obligatoria: Politicas y Actores (1 ${ }^{\text {a }}$ ed., pp. 195-2014). Buenos Aires. Retrieved from http: //www. buenosaires.iipe.unesco.org

Hinojo, F., Fernández, F., \& Aznar, I. (2002). Las actitudes de los docentes hacia la formación en tecnologías de la información y comunicación (TIC) aplicadas a la educación. Contextos Educativos: Revista de Educación, (5), 253-270. Retrieved from https://dialnet.unirioja.es/servlet/articulo? codigo=498346

Ibieta, A., Hinostroza, J. E., Labbé, C., \& Claro, M. (2017). The role of the Internet in teachers' professional practice: activities and factors associated with teacher use of ICT inside and outside the classroom. Technology, Pedagogy and Education, 26(4), 425-438. https ://doi.org/10.1080/1475939X.2017.1296489

Jara, I., \& Claro, M. (2012). La Política de TIC para escuelas en Chile (red enlaces): Evaluación de habilidades digitales. Revista Cientifica Iberoamericana de Tecnologì Educativa, 1(1). Retrieved from http: //www . uajournals . com/campusvirtuales/campusvirtuales/numeros/1.pdf\#page=79

Jaramillo, C., \& Chávez, J. (2015). TIC y educación en Chile: Una revisión sistemática de la literatura. Nuevas Ideas en Informática Educativa TISE. Retrieved from http://repositorio.minedu.gob.pe/handle/123456789/4569

Koenigstorfer, J., \& Groeppel-Klein, A. (2012). Consumer acceptance of the mobile Internet. Marketing Letters, 23(4), 917-928. https : //doi .org/10.1007/s11002-012-9206-1

Lam, S. Y., Chiang, J., \& Parasuraman, A. (2008). The effects of the dimensions of technology readiness on technology acceptance: An empirical analysis. Journal of Interactive Marketing, 22(4), 19-39. https://doi.org/10.1002/DIR. 20119

Larasiti, N., Widyawan, \& Santosa, P. (2017). Technology Readiness and Technology Acceptance Model in New Technology Implementation Process in Low Technology SMEs. International Journal of Innovation, Management and Technology, 8. https://doi.org/10.18178/ijimt.2017.8.2.713

Lin, C.-H., Shih, H.-Y., \& Sher, P. (2007). Integrating Technology Readiness into Technology Acceptance: The TRAM Model. Psychology \& Marketing, 24. Retrieved from file:///C:/Users/Valentina/Downloads/Lin_et_al-2007-Psychology_\%2526_Marketing.pdf

Marques, B., Villate, J., \& Carvalho, C. (2011). Applying the UTAUT model in Engineering Higher Education: Teacher's Technology Adoption. En CISTI 2011 - Conferência Ibérica de Sistemas e Tecnologias de Informação (pp. 1-6). Retrieved from https://repositorio-aberto.up.pt/handle/10216/107043

Martín, A., García, Á., \& Muñoz, J. (2014). Factores determinantes de adopción de blended learning en educación superior. Adaptación del modelo UTAUT. Educación XX1, 17(2). https://doi.org/10.5944/educxx1.17.2.11489

Nunnally, J. (1978). Psychometric Theory. McGraw-Hill. Retrieved from https://books.google.cl/ books/about/Psychometric_theory.html?id=WE59AAAAMAAJ\&redir_esc=y

Oliver, R. (1980). A Cognitive Model of the Antecedents and Consequences of Satisfaction Decisions. Journal of Marketing Research, 17(4), 460. https : //doi.org/10.2307/3150499

Oye, N.D., A.Iahad, N. \& Ab.Rahim, N (2014). The history of UTAUT model and its impact on ICT acceptance and usage by academicians. Educ Inf Technol, 19, 251-270. https://doi.org/10.1007/s10639-012-9189-9

Parasuraman, A. (2000). Technology Readiness Index (Tri): A Multiple-Item Scale to Measure Readiness to Embrace New Technologies. Journal of Service Research, 2(4), 307-320.

https://doi.org/10.1177/109467050024001 
Parasuraman, A., \& Colby, C. (2015). An Updated and Streamlined Technology Readiness Index. Journal of Service Research, 18(1), 59-74. https://doi.org/10.1177/1094670514539730

Parasuraman, A., \& Colby, C. L. (2001). Techno-Ready Markeitng: How and why customers adopt technology. Nueva York: Free Press. Retrieved from http://ecsocman.hse.ru/text/19171626/

Pelgrum, W. (2001). Obstacles to the integration of ICT in education: results from a worldwide educational assessment. Computers \& Education, 37(2), 163-178.

https : //doi.org/10.1016/S0360-1315(01)00045-8

Prensky, M. (2011). Enseñar a Nagivos Digitales. (Sm, Ed.). Madrid.

Puentes, A., Roig, R., Sanhueza, S., \& Friz, M. (2014). Concepciones sobre las Tecnologías de la Información y la Comunicación (TIC y sus implicaciones educativas: Un estudio exploratorio con profesorado de la provincia de Ñuble, Chile. Revista Iberoamericana de Ciencia Tecnología y Sociedad, 8(22), 75-88. Retrieved from

http://www.scielo.org.ar/scielo.php?pid=S185000132013000100005\&script=sci_arttext\&tlng=en

Pynoo, B., Devolder, P., Tondeur, J., van Braak, J., Duyck, W., \& Duyck, P. (2011). Predicting secondary school teachers' acceptance and use of a digital learning environment: A cross-sectional study. Computers in Human Behavior, 27(1), 568-575. https : //doi .org/10.1016/J . CHB . 2010.10.005

Raman, A., \& Rathakrishnan, M. (2018). FROG VLE: Teachers' technology acceptance using utaut model. International Journal of Mechanical Engineering and Technology, 9(3), 529-538. Retrieved from file:///C:/Users/Valentina/Downloads/IJMET_09_03_055.pdf

Ramírez-Correa, P., Mello-Mariano, T., Alfaro-Perez, J., Grandon, E., \& Araya, S. (2018). Exploring the variables that explain the intention to continue using Smartphone. En 2018 13th Iberian Conference on Information Systems and Technologies (CISTI) (pp. 1-4). IEEE. https://doi.org/10.23919/CISTI.2018.8399395

Ramírez-Correa, P., Rondán-Cataluña, F., \& Arenas-Gaitán, J. (2014). An empirical analysis of mobile Internet acceptance in Chile. Information Research, 19. Retrieved from http://www . informationr.net/ir/19-3/paper635.html\#. W4WhxOhKhPY

Raquimán, P. (2014). Representaciones sobre el cambio en el uso de las TICs. Relatos de vida de profesores. Revista Iberoamericana de Educación, 65, 75-90. Retrieved from www . latindex. unam.mx

Ringle, C., Wende, S., \& Will, A. (2015). SmartPLS 2.0. Recuperado 22 de agosto de 2018, a partir de https://scholar.google.com/citations?user=y5F176wAAAA Jhl=es\#d=gs_md_cita$\mathrm{d} \& \mathrm{p}=\& \mathrm{u}=\% 2 \mathrm{~F}$ citations $\% 3 \mathrm{Fv}$ iew_op $\% 3 \mathrm{Dv}$ iew_citation $\% 26 \mathrm{hl} \% 3 \mathrm{Des} \% 26$ user $\% 3 \mathrm{Dy} 5 \mathrm{~F} 176 \mathrm{wAAAAJ} \% 26$ citation_for_view\%3Dy5F176wAAAAJ\%3Au5HHmVD_u08C\%26tzom\%3D180

Rogers, E. (1962). Diffusion of Innovations (Third Edi). Recuperado a partir de https://teddykw2.files . wordpress . com/2012/07/everett-m-rogers-diffusion-of-innovations .pdf

Seol, S. H., Ko, D. S., \& Yeo, I. S. (2017). Ux analysis based on TR and UTAUT of sports smart wearable devices. KSII Transactions on Internet and Information Systems, 11(8), 4162-4179. https://doi.org/10.3837/tiis.2017.08.024

Silva, J., Gros, B., Garrido, J., \& Rodríguez, J. (2006). Estándares en tecnologías de la información y la comunicación para la formación inicial docente : situación actual y el caso chileno. Revista Iberoamericana de Educación, 38, 1-17. https://doi.org/10.5944/educxx1.17.1.10707

Sunkel, G. (2006). Las tecnologías de la información y la comunicación (TIC) en la educación en América Latina. Una exploración de indicadores. Santiago: Publicación de las Naciones Unidas Retrieved from . https: //repositorio. cepal .org/bitstream/handle/11362/6133/S0600907_es .pdf?sequence=1

Thompson, R., Higgins, C., \& Howell, J. (1991). Personal Computing Toward a Conceptual Model of Utilization. Management Information Systems Quarterly, 15(1). Retrieved from http://aisel.aisnet.org/misq/vol15/iss1/7

UNESCO (2004). Las Tecnologías de la información y la comunicación en la formación docente: guía de planificación; 2002. Paris. Retrieved from http://unesdoc.unesco.org/images/0012/001295/129533s.pdf

Valencia-Molina, T., Serna-Collazos, A., Ochoa-Angrino, S., Caicedo-Tamayo, A., Montes-González, J., \& Chávez-Vescance, J. (2008). COMPETENCIAS Y ESTÁNDARES TIC desde la dimensión pedagógica Una perspectiva desde los niveles de apropiación de las TIC en la práctica educativa docente. Retrieved from http://www.unesco.org/new/fileadmin/MULTIMEDIA/FIELD/Santiago/pdf/Competencias-estandares-TIC.pdf

Venkatesh, V., Morris, M., Davis, G., Davis, F., Smith, R., \& Walton, S. (2003). User acceptance of informatioon technology: Toward a unified view. Source: MIS Quarterly, 27(3), 12. Retrieved from http://www.jstor.org/stable/30036540 
Villegas, M., Mortis, S., García, R., \& Del Hierro, E. (2017). Uso de las TIC en estudiantes de quinto y sexto grado de educación primaria. Apertura, 9(1), 50-63. https://doi.org/10.18381/Ap.v9n1.913

Viñals, A., \& Cuenca, J. (2016). El rol del docente en la era digital. Revista Interuniversitaria de Formación del Profesorado, 30, 103-114. Retrieved from http: //www.redalyc.org/pdf/274/27447325008.pdf

Walczuch, R., Lemmink, J., \& Streukens, S. (2007). The effect of service employees' technology readiness on technology acceptance. Information and Management, 44(2), 206-215. https://doi.org/10.1016/j.im.2006.12.005

Yang, S. C., \& Huang, Y.-F. (2008). A study of high school English teachers' behavior, concerns and beliefs in integrating information technology into English instruction. Computers in Human Behavior, 24(3), 10851103. https://doi.org/10.1016/J.CHB.2007.03.009

Zampieri, M., Lindner, D., Flores, L., \& Pellegrin, T. (2014). Compreensao da satisfacao e intencao de continuidade de uso da tecnologia por meio do indice de prontidao tecnològica. Review of Administration and Innovation, 11(3), 101. https://doi.org/10.11606/rai.v11i3.100217

Zanardo, A., \& Dadalto, M. (2010). Análise do comportamento do consumidor. En Análise do Comportamento: Pesquisa, Teoria e Aplicação (pp. 283-304). Vitória. Retrieved from http: //www. intercom.org.br/papers/regionais/sudeste2010/resumos/R19-0737-1.pdf

V. López-Pérez is Computer Engineer and Academic Coordinator of the Admission and Academic Records Office at Universidad del Bío-.Bío. She obtained her Master in Business Administration at Universidad del Bío-Bío, Chile.

P. Ramírez-Correa is Associate Professor of Engineering at the Universidad Católica del Norte (Chile), visiting professor at University of Seville (Spain), and at AUT's Business School (New Zealand). Dr. Ramirez-Correa is author of more than 40 publications in international indexed journals in the field of information systems, learning and ICT. He has published his work in journals such as Computers \& Education, Journal of Theoretical and Applied Electronic Commerce Research, Telematics and Informatics, and Journal of Research in Interactive Marketing.

E.E. Grandón is Associate Professor of Information Systems at the Universidad del Bío-Bío (Chile), visiting professor at UNAM (México), UNAL (Colombia), and Universidad de Coahuila (Mexico). Dr. Grandón is author of more than 30 publications in international indexed journals in the field of information systems and business. She has published her work in journals such as Information \& Management, Journal of Business Research, Journal of Internet Commerce, and Journal of Global Information Technology Management. 
